\title{
Comparison of sampling methods to evaluate aphid populations (Homoptera, Aphidinea) alighting on apricot trees
}

\author{
L Avinent, A Hermoso de Mendoza, G Llacer * \\ Instituto Valanciano de Investigaciones Agrarias (IVIA), Departamento de Protección Vegetal, \\ Apartado Oficial, E46113 Moncada, Valencia, Spain
}

(Received 28 May 1992; accepted 6 May 1993)

\begin{abstract}
Summary - Alate aphid populations landing on apricot trees were studied in an orchard during Spring, 1990 in Valencia, Spain. The sticky tree method was introduced which consisted of spraying leaves and shoots of the tree with a sticky substance; aphids landing there remained stuck. Aphid collections with this method were compared with those obtained using green water pan traps and sticky fishing-line traps. Aphis gossypii was the most abundant species landing on apricot trees (leaves and shoots), while Aphis spiraecola was only abundant on shoots. Collections of aphids using either the fishing-line traps or the green traps were not representative of the actual population of aphids landing on apricot trees; captures in green traps were similar to captures on shoots and captures with fishing-line traps were similar to captures on leaves. Since neither of the 2 traps was able to provide a good estimation of the aphid populations landing on apricot trees, both traps must be used if the sticky tree method is not used.
\end{abstract}

aphid / collection trap / sticky tree / apricot tree

Résumé - Comparaison de méthodes d'échantillonnage pour évaluer l'atterrissage des populations de pucerons sur abricotier. Le but de l'essai était d'étudier les populations de pucerons ailés qui atterrissent sur des abricotiers. Pour cela, la technique des arbres englués a été essayée; elle consiste à pulvériser sur les feuilles et les jeunes pousses de l'arbre une substance collante. Les pucerons capturés à l'aide de cette technique ont été comparés à ceux capturés par des pièges verts à eau et par des pièges à fils englués. L'essai a été réalisé au printemps 1990 dans un verger d'abricotiers à Valence (Espagne). L'espèce la plus abondante sur les arbres englués (feuilles et pousses) était Aphis gossypii, tandis qu'A spiraecola était abondant seulement sur les pousses. Les pièges à fils englués et les pièges verts à eau ne donnent pas une image exacte des pucerons qui atterrissent sur les arbres: les pucerons capturés par les pièges verts à eau étaient semblables à ceux qui atterrissaient sur les pousses, tandis que ceux capturés par les pièges à fils englués étaient semblables à ceux qui atterrissaient sur les feuilles. Les 2 types de pièges doivent donc être utilisés pour analyser les populations de pucerons qui atterrissent sur les arbres, si la technique de l'arbre englué n'est pas utilisée.

puceron / piège / arbre englué / abricotier

* Correspondence and reprints 


\section{INTRODUCTION}

In a previous work (Avinent et al, 1991) sticky fishing-line traps were used in Valencia (Spain) to determine the general aphid population in apricot tree orchards where sharka virus (plum pox virus, PPV) was spreading. Collections of alate aphids intercepted in flight by these traps were compared with collections of alate aphids which landed in coloured (yellow and green) water pan traps. Species composition was different for each type of trap. Aphis gossypii was the most abundant species in the orchards studied, followed by Aphis spiraecola. A spiraecola is a vector of the sharka virus (Leclant, 1973) but $A$ gossypii had never been assayed, or at least reported as a vector of the sharka virus. Our experiments currently in progress have not provided positive results either.

Since for the non-persistent virus the attack flight of aphids is enough for transmission, the present work was developed in 1990 to determine which aphids were actually alighting on apricot leaves and shoots (first objective). For this purpose, we introduced the sticky tree method, which consists of spraying the leaves of the apricot trees with a sticky substance; the aphids landing there remain stuck.

Trap collections provide data on the aphids flying inside the orchards but we did not know whether these aphids landed on the trees or not. So aphid populations collected with the sticky tree method were compared with those from green and fishing-line traps in order to determine whether capture with any of these traps gave a clear image of aphid populations landing on apricot trees (second objective). Yellow traps were not utilized in this study because they are very selective for A spiraecola (Seif, 1988; Labonne et al, 1989; Avinent et al, 1991). The results of both objectives are reported here.

\section{MATERIALS AND METHODS}

The study was conducted in the Spring of 1990 (11th23rd May) in an irrigated apricot tree orchard (0.4 ha) in Benimodo (Valencia, Spain) located in a citrus area.

The sampling methods for alate aphids were as follows:

\section{Green traps}

These traps were round pans $30 \mathrm{~cm}$ in diameter and $10 \mathrm{~cm}$ deep placed on a metal stand $1.5 \mathrm{~m}$ high. The insides were painted green and filled with water. A fungicide (Captan) was added to the water to avoid aphid contamination by fungi. Two of these traps were used. They were placed at 2 locations in the orchard, inside a square space bordered by 4 trees, $9 \mathrm{~m}$ apart from fishing-line traps. The green colour used was a mixture (1:1) of yellow enamel (Titanlux synthetic enamel, 568) and green enamel (Titanlux synthetic enamel, 516 ), to obtain a colour index similar to that of adult apricot leaves. The colour index was measured with a Minolta CR-200 colorimeter. Afterwards, the colour reflective spectrogram for the green trap, leaves and shoots of the apricot trees was determined at $10-\mathrm{nm}$ intervals (between 400 and $700 \mathrm{~nm}$ ) with a Labscan II spectrocolorimeter (fig 1).

\section{Fishing-line traps (Labonne et al, 1983)}

These consisted of a wooden frame $(31 \times 28 \mathrm{~cm})$, and transparent polyamide threads $(0.4-\mathrm{mm}$ thick), fixed vertically $3.5 \mathrm{~mm}$ apart. The actual capture area (25.5 $\times 26.5 \mathrm{~cm}$ ) was sprayed with a transparent sticky substance (Soveurode aerosol). Four of these traps were used; they were suspended $160 \mathrm{~cm}$ above ground level by means of 4 fixed metal stands. Two traps were orthogonally placed $1 \mathrm{~m}$ apart inside a square space allowed by 4 trees (fig 2), at 2 locations in the orchard.

\section{Sticky tree}

This method consists of spraying the part of the tree under study with a transparent sticky substance (Soveuroda aerosol); the aphids landing there remained

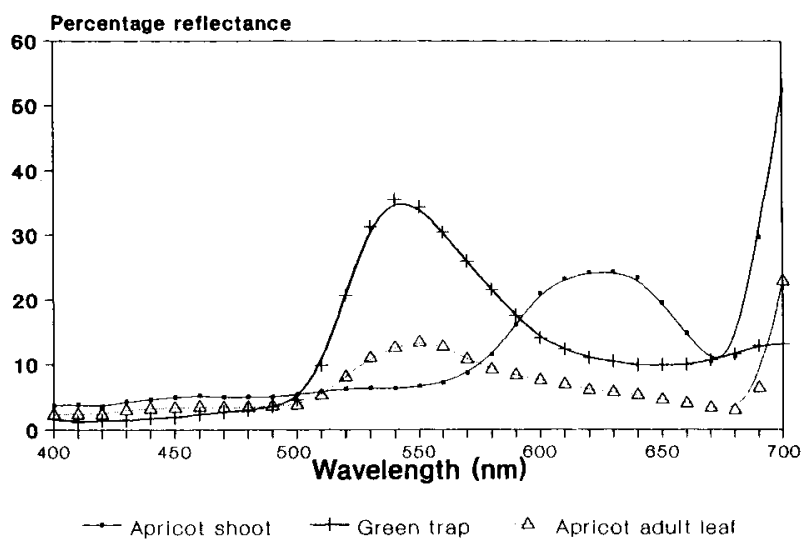

Fig 1. Reflective wavelength spectrogram of green trap and apricot shoots and leaves. 
stuck. Leaves and shoots sprayed were marked with plastic curtain rings for easy identification when collected. To remove aphids that were stuck, leaves and shoots were plunged (once they had been removed from the tree) in pots filled with turpentine in the field. Once in the laboratory, leaves and shoots were taken from the pots, leaving the aphids in the turpentine; then the contents of the pots were filtered and the aphids remained on the plastic filter; the process went on as for the fishing-line traps (Labonne et al, 1983).

The sampling procedure was as follows (fig 2): 2 groups of 4 apricot trees each were chosen. Within each group, the 4 trees made up the vertices of a square space. Two branches per tree were chosen, placed at 2 different heights but all facing toward a central point. The lowest sampled branch was approximately the height of the fishing-line traps $(160 \mathrm{~cm})$; the highest branch was $\approx 3 \mathrm{~cm}$, to collect aphids flying above the trees. The position of the branch sampled is shown in figure 2. It was assumed that the whole of the sampled branches in the 4 trees provides an estimation of aphids landing on a tree. On each branch 10 leaves (upper surface) and 1 shoot were sprayed (randomly chosen along the whole branch). At the beginning leaves were sprayed on both surfaces, but we gave up spraying leaves on the lower surface because a toxic effect was observed.

The aphids caught with these 3 methods were collected at $\approx 2-d$ intervals during the $13-d$ sampling period, maintained in alcohol, and later identified according to the method of Ilharco (1965).

To compare the relative percentages of species caught among the 3 different traps, a factorial analysis of correspondences was made (FAC); the clustering method of Lance and Williams (1967) was used. For statistical determination of total real values, an analysis of variance was made and the Duncan's multiplerange test $(95 \%)$ was used to compare means. This
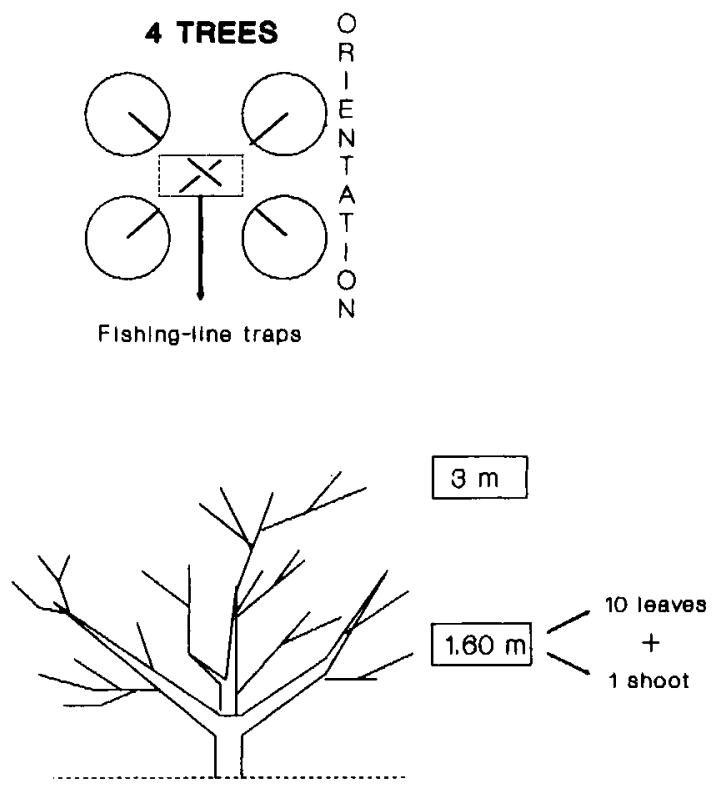

Fig 2. Location of the fishing-line traps and of the sampled branches of the sticky tree method. analysis was just applied to the sticky tree method (leaves and shoots). We focussed on height preference; we considered this effect to be fixed.

\section{RESULTS AND DISCUSSION}

A total of 16358 aphids was caught during the study period. We shall emphasize only the most abundant species or groups of species: Aphis gossypii (Glover, 1877), Aphis spiraecola (Patch, 1914), Hyalopterus pruni (Geoffroy, 1762), Myzus persicae (Sulzer, 1776), Pemphigidae spp and Toxoptera aurantii (Boyer de Fonscolombe, 1841). The others were very diverse, including several species but with few specimens per species. Figure 3 shows the percentages of these species for the 3 types of sampling methods, dividing the sticky tree method into leaves and shoots.

As the study was in progress in the orchard, a discolouration of green traps was observed (they turned yellowish) so we also considered the percentages of the 2 initial dates of collection and the last 2 dates separately (fig 4). Information is presented for only the 2 most important species: A gossypii and $A$ spiraecola. The percentages reached by these 2 species with each sampling method show the relative efficiency of the different methods used. Figure 5 presents the dendrogram for the different sampling methods obtained by factorial analysis of correspondences (FAC) applied to data from figure 4. Factors studied were: type of trap (green, fishing-line, leaves and shoots) and date of collection (initial and last collections).

With all the methods used, the most abundant species in the orchard studied was $A$ gossypii, which agrees with the data obtained in a previous study with fishing-line traps (Avinent et al, 1991).

Figures 3 and 4 show that percentages for the 2 most abundant aphid species were different for leaves and for shoots: $A$ gossypii was more abundant on leaves than on shoots; $A$ spiraecola was far more abundant on shoots than on leaves.

Percentages for aphid species caught on leaves were very similar to those for fishing-line traps (fig 3): in both cases $A$ gossypii was the most abundant species, with percentages of $\approx$ $90 \%$. This, together with the fact that leaves constitute the largest proportion of the tree volume, makes it necessary to continue the trans- 


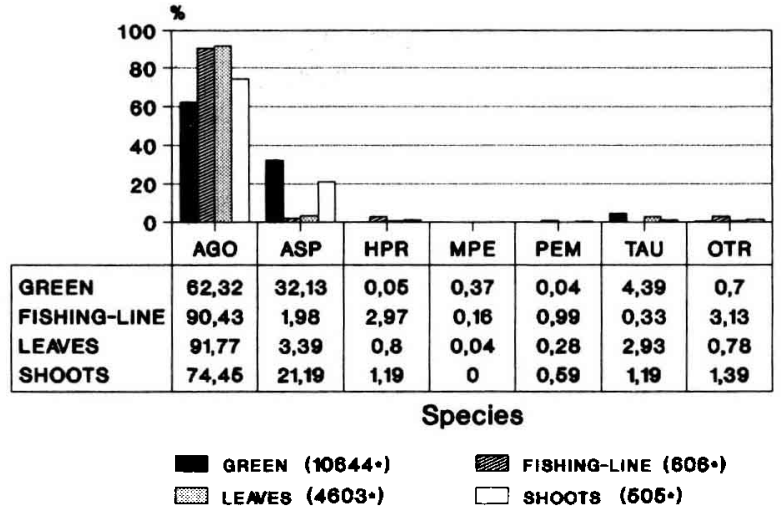

Fig 3. Percentages between species for the different sampling methods and total number of aphids.

mission tests of the sharka virus by $A$ gossypii to determine its potential vector ability. A spiraecola was not abundant either on the adult leaves of the apricot trees or in the fishing-line traps. Relative FAC distances between these 2 samplings methods were short (fig 5), and therefore captures with fishing-line traps and leaves were very similar. This result was also quite similar to that obtained by Labonne and Lauriaut (1991) in the southeast of France in an assay conducted in parallel with ours. Experiments carried out with the same technique in potatoes, and sticky baitplants (Derron et al, 1989) also showed the similarity between collections with fishing-line traps and collections with the sticky plants.

The dendrogram (fig 5) shows that captures on shoots were quite similar to the initial captures with green traps (before discolouration), but they were very different from the last collections with discoloured green traps. Actually, the percentages for green traps changed largely (fig 4). We believe that the change in the colour of the trap produced an attraction to A spiraecola (as yellow traps do) and in this way, percentages of this species increased markedly in the last collections, decreasing the percentages of $A$ gossypii. An increase in $A$ spiraecola was also observed on shoots (between the first and last collections) although it was smaller than the increase for the green traps. The actual values for green traps are those from the first collections (since it was the green selected) and with these data a high similarity was obtained between green traps and shoots (fig 5).

A spiraecola which was not very abundant on leaves but was abundant on shoots, which agrees with Moericke (1955) in that some aphids are more attracted to higher reflectance from new developing leaves (the yellow appearance

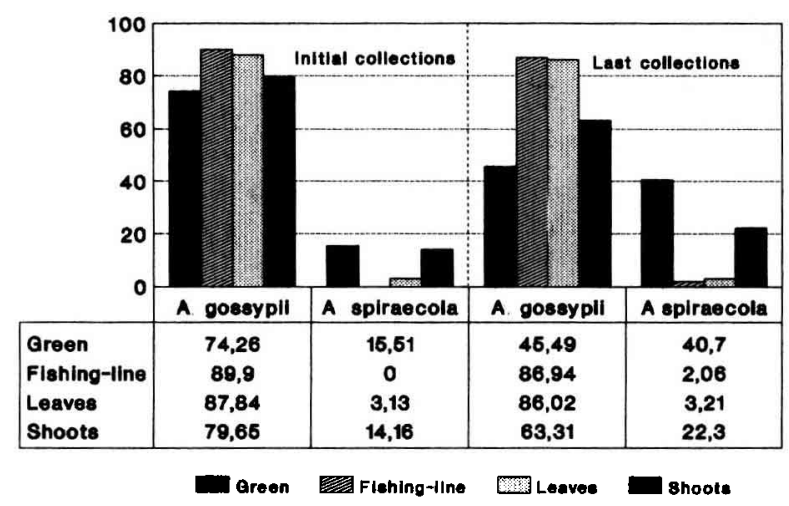

Fig 4. A gossypii and A spiraecola percentages for the different sampling methods and collection date.

correlated with higher available nitrogen content of the sap) than to the lower reflectance of mature (green) leaves of the same plant (fig 1). Moreover, Prokopy and Owens (1983) hypothesized that a positive response to yellow pigments may be characteristic of major proportion of foliage-seeking insects, although there may be some exceptions. A gossypii would be one of these exceptions, since a smaller number of specimens was collected in yellow traps than in green traps (Avinent et al, 1991) and, moreover, shoots attracted this species in lower rates than adult leaves did. Figure 1 shows higher reflectance for shoots than for leaves.

To study the possible vectors of sharka in apricot trees it is necessary to use the sticky tree method, or the simultaneous use of fishing-line traps and green traps; the fishing-line traps to evaluate aphid population on leaves, and the green traps to evaluate aphid population on shoots. Care must be taken to avoid discolouration of the green trap.

For the sticky-tree method, height had an influence in the collection of $A$ gossypii when considering the total number of aphids caught (table I):

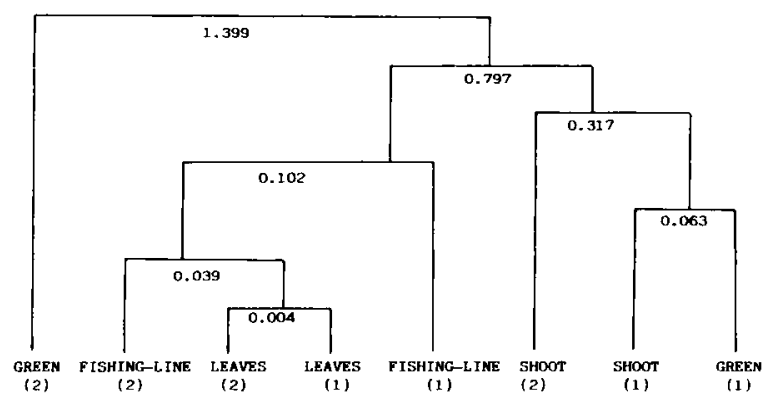

Fig 5. Dendrogram for the different sampling methods. $\chi^{2}$ distances following a cluster analysis of the 2 first factors of the FAC. (1) initial collections; (2) last collections. 
more specimens were caught in the basal branches and shoots than on those on top. For $A$ spiraecola there were no significant differences (Duncan, 95\%) in the number of aphids caught on the top and basal leaves, but there were on shoots: the number of $A$ spiraecola was higher on the top shoots than in the basal shoots. These differences, depending on height, were also observed when captures with fishing-line traps at 2 heights were studied (Avinent et al, 1991).

\section{CONCLUSIONS}

Although $A$ gossypii is the most abundant species in the orchards studied as well as the most abundant species landing on apricot trees, $A$ spiraecola must be taken into account because of its presence on shoots and its well-known ability to transmit sharka virus. The transmission assays with $A$ gossypii should be continued to determine its potential transmission ability of the sharka virus.

Neither the fishing-line traps nor green traps give a real image of the aphid population landing on apricot trees: green traps are similar to shoots, and fishing-line traps are similar to adult leaves. Both must be used to determine the aphid population landing on apricot trees if the sticky tree method is not used.

Table I. Average number of aphids caught in leaves and shoots.

\begin{tabular}{|c|c|c|c|c|}
\hline & \multicolumn{2}{|c|}{ Leaves } & \multicolumn{2}{|c|}{ Shoots } \\
\hline & $1.6 \mathrm{~m}$ & $3 m$ & $1.6 \mathrm{~m}$ & $3 m$ \\
\hline A gossypii & $299.5 a^{a *}$ & $228.5 \mathrm{~b}$ & $25.2^{\mathrm{a}}$ & $21.7^{b}$ \\
\hline A spiraecola & $4.6 \mathrm{a}$ & 14.9 a & $4.0^{b}$ & $9.3^{a}$ \\
\hline Hpruni & $2.0^{a}$ & $2.6 a$ & $0.0^{a}$ & $0.7^{a}$ \\
\hline$M$ persicae & $0.2^{a}$ & $0.0^{a}$ & $0.0^{a}$ & $0.0^{a}$ \\
\hline Phemphigidae & $0.6 \mathrm{a}$ & $1.0 \mathrm{a}$ & $0.1 \mathrm{a}$ & $0.2^{a}$ \\
\hline$T$ aurantii & $10.1^{a}$ & $6.7 \mathrm{a}$ & $0.0^{a}$ & $0.7^{a}$ \\
\hline Others & $2.0 \mathrm{a}$ & $2.5 \mathrm{a}$ & $0.0^{a}$ & $0.9^{a}$ \\
\hline
\end{tabular}

\footnotetext{
* For a known species, and separating leaves and shoots, the average values followed by the same letter are not significantly different (Duncan's test, 95\%).
}

\section{ACKNOWLEDGMENTS}

This study has been supported by the Instituto Nacional de Investigaciones Agrarias (INIA) of Spain (project No 8133). L Avinent was granted a predoctoral fellowship by the Conselleria de Cultura, Educación y Ciencia, Generalitat Valenciana. The authors express their appreciation to S Garcia (EUITA, Valencia) for his help in locating the experimental orchards: to $E$ Carbonell (IVIA, Valencia) for assisting in the statistical analyses, to C Calvo (IATA, Valencia) for assisting in the color spectrograms, and to A Borrás (IVIA, Valencia) for helping with the English translation.

\section{REFERENCES}

Avinent L, Hermoso de Mendoza A, Llacer C (1991) Comparison of traps for captures of alate aphids (Homoptera, Aphidinea) in apricot tree orchards. agronomie 11, 613-618

Derron JO, Goy G, Genthon M (1989) Le piégeage des pucerons ailés: potentialités et limites de différents types de pièges. In: Euraphid Network: Trapping and Aphid Prognosis (Cavalloro R, ed) Comm Commun Eur, Brussels, 71-82

Ilharco FA (1965) Afideos das fruteiras de Portugal continental. Agron Lusitana 27, 1, 5-86

Labonne G, Fauvel G, Leclant F, Quiot JB (1983) Intérêt des pièges à fils dans l'étude des populations de pucerons ailés. agronomie 3, 4, 315-326

Labonne G, Lauriaut F, Quiot JB (1989) Comparaison de trois types de pièges pour l'échantillonnage des populations des pucerons ailés. agronomie 9, 547557

Labonne G, Lauriaut F (1991) Evaluation du nombre de pucerons qui atterrissent sur un arbre en relation avec la dissémination du plum pox virus. Phytopathol Mediterr 30, 167-172

Lance GN, Williams WT (1967) Mixed data classificatory programs. 1. Agromerative system. Aust Comp I, 1, 50-20

Leclant F (1973) Aspect écologique de la transmission de la Sharka (plum pox) dans le sud-est de la France. Ann Phytopathol 5, 4, 431-439

Moericke $V$ (1955) Uber die Lebensgewohnheiter der Geflugelten Blattlause unter Besonderer Berucksichtigung des Verhaltens beim Landern. Z Angew Entomol 37, 29-91

Prokopy RJ, Owens ED (1983) Visual detection of plants by herbivorous insects. Ann Rev Entomol 28, 337-364

Seif AA (1988) Comparison of green and water yellow traps for sampling citrus aphids at the Kenya coast. E Afr Agric For J 53, 3, 159-161 